\title{
Alberto Sartoris' Contribution to the Architectural Culture of Theatre: From the Private Theatre of Casa Gualino to the Avant-garde Theatre for Geneva
}

\author{
Cinzia Gavello \\ Department of Architecture and Design (DAD), Politecnico di Torino, Turin, Italy \\ Email address: \\ cinzia.gavello@polito.it \\ To cite this article: \\ Cinzia Gavello. Alberto Sartoris' Contribution to the Architectural Culture of Theatre: From the Private Theatre of Casa Gualino to the \\ Avant-garde Theatre for Geneva. American Journal of Art and Design. Vol. 4, No. 3, 2019, pp. 22-30. doi: 10.11648/j.ajad.20190403.11
}

Received: August 23, 2019; Accepted: September 9, 2019; Published: September 21, 2019

\begin{abstract}
In the last twenty years Alberto Sartoris has been the subject of numerous celebrative publications: despite this critical fortune, catalogs of exhibitions and essays dedicated to him are mostly referred to specific episodes of his career, the aspects of his relationship with the architecture of the theater has always remained in the background, in spite of this very rich bibliographic production. The aim of this research is therefore to add a further piece to the complex artistic-theoretical activity of such a multifaceted person, analyzing Sartoris' contribution to architecture of the theatre through the analysis of his main projects and his theoretical contribution to design. His eclectic personality allowed him to successfully apply in many disciplines, so as to be recognized as one of the most important precursors of rational architecture in Italy and abroad. Sartoris' "lyrical rationality" is also clearly visible in his experimental avant-garde theatre project of 1929 whereby he can coherently deal with theatre themes, favoring a rational stage performance, with the involvement of large masses of spectators, a trend typical of architecture in the first half of the twentieth century.
\end{abstract}

Keywords: Alberto Sartoris, Axonometries, Riccardo Gualino, Geneva Avant-garde Theatre, Gli Elementi Dell'Architettura Funzionale, Rationalism

\section{Introduction}

Alberto Sartoris (Turin, Italy, 1901-Cossonay, Switzerland, 1998), Italian-Swiss architect, author of books and art promoter, is considered by critics and existing literature one of the central personalities of twentieth-century European architecture [1].

Despite the fact that his main books have been published by an Italian publishing house, Ulrico Hoepli, and notwithstanding being repeatedly defined as the "father of rationalism Italian" and the "founder of the new architectural culture" [2], curiously in Italy Sartoris seems to have never enjoyed the great fortune and recognition due to the spectacularity of his projects [3]. After an initial period of training in Turin, judged to be a Fascist in the 1930s, Sartoris was therefore able to conduct his professional activity in Switzerland, with works that included not only residential and religious constructions but also architecture of the theater: with these projects, in the following years Sartoris has successfully and stubbornly brought to light a so-called "project radicalism", with a stainless faith in rational architectural. Such obstinacy sounded like an offense to the Italian innovators of the time that was certainly difficult to tolerate.

The numerous themes related to the study of theater's architecture developed by Sartoris, almost completely ignored by historiographic criticism, are made possible through the analysis of the documents and drawings kept by the Archives de la construction modern of the École Polytechnique Fédérale de Lausanne, in Switzerland, and through the critical reading of his first famous book, Gli elementi dell'architettura funzionale. Sintesi panoramica dell'architettura moderna published in April 1932 [4].

The architecture of the theatre was a well-defined chapter in Sartoris' career and, at the same time, it was closely linked to his reflections on the architectural organism throughout his long career, both professional and academic. Some of Sartoris' projects, realized from 1925 onwards, show an implicit 
futurist influence, for example observing the works of Sant'Elia, Enrico Prampolini, Luigi Colombo (better known as Fillìa) or Nicolay Diulgheroff, while others openly denounce a reflection on the works of important protagonists of the so-called "rational-functionalist" architecture, such as Walter Gropius, Marcel Breuer, Le Corbusier or Robert Mallet-Stevens. Sartoris' attempt to combine the originality of the Italian Futurist Movement, whose manifesto published by Filippo Tommaso Marinetti dates back to 1909, and themes of European rationalism are clearly evident if one looks above all at the little-known drawings of his theater projects.

\section{Methods}

Considering the complexity and the articulation of the topic, this research path required a meticulous work of documentation, based especially on primary sources, so far never carried out by the authors who have faced the examination of the professional, literary and academic career of Sartoris. In fact, it would not be possible to understand the essence about the Sartoris' "itinéraire magique" without knowing in depth his experiences since the thirties [5].

The overall interpretative framework has been traced following the retrieval of documents (letters, drawings, projects and photographs) kept at the Alberto Sartoris Fund of the Archives de la construction moderne of the École Polytechnique Fédérale de Lausanne; fundamental for investigating specific events related to Sartoris' academic career were the documents found at the Archivio Storico Ulrico Hoepli in Milan. In particular, the rich correspondence kept by EPFL although sometimes incomplete and not catalogued, made possible to retrace for the first time the main phases that led to the preparation of the project of the avant-garde theatre for Geneva, as well as the historical events linked to the project for Gualino.

The vastness of these documents has allowed in particular to relate the literary activity of Sartoris with that of the designer, according to the same principle stated by Fillì in 1932, who described him at the same time as a propagandist in favor of new architecture, as well as the "best theorist" and the "purest creator" [6]. The identification of critical relationships between the various facets that Sartoris manages to give to the architect's profession is made possible by the analysis of his projects and the different methods of representation and communication that he uses: from written text, to photography, to drawing and axonometry.

\section{Sartoris' Theatre for Gualino and the Avant-garde Theater for Geneva}

Among Sartoris' first projects, the private theatre for the famous industrialist and collector from Biella, Riccardo Gualino, realized in 1925 in collaboration with the Turin painter Felice Casorati (see Figure 1), took on great importance in the Sartoris' career: images of the interior of this small building appeared in the most popular magazines and architectural journal of that time.

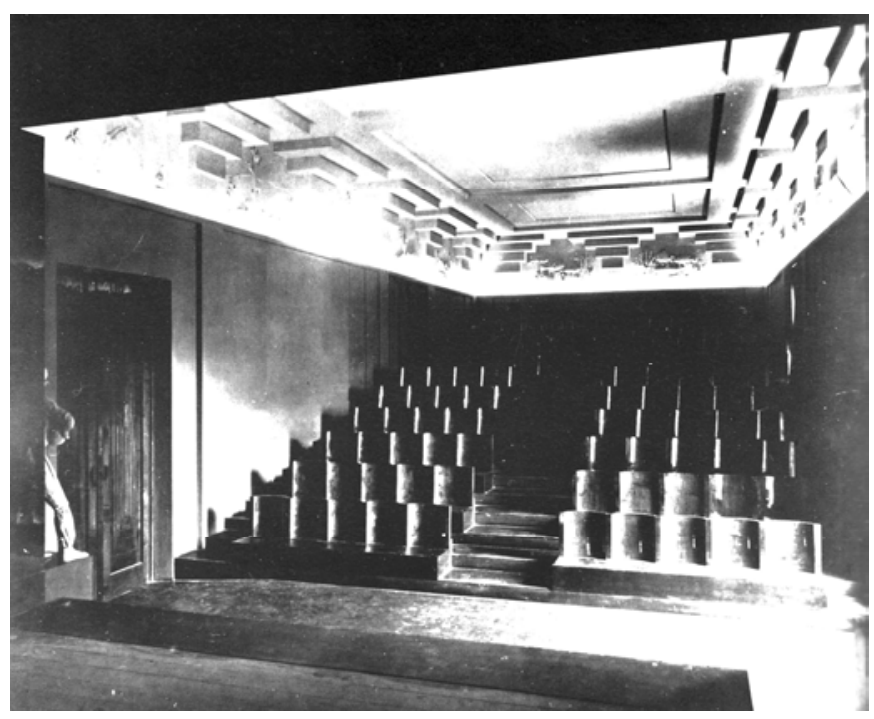

Figure 1. Private theatre for Riccardo Gualino. Photograph of the hall with chalks realized by Casorati (L. Pianzola, Alberto Sartoris, da Torino all'Europa. Milan: Alberto Greco Editore, 1990, 38).

Belonging to the period of Turin formation, the perspective views of the project of the private theatre for Gualino are a precious testimony: this well-known perspectives of the interiors and the drawings of furnishings, created by Sartoris and Casorati, highlight for the first time an almost inedited image of Sartoris-designer, as well as the essentiality and cleanliness that indelibly characterize his personal and recurrent representation tool, that is the perspective at first and the axonometry later. The project of this theater, considered a masterpiece of the Turin art déco, seems to highlight the realization of a "metaphysical space" of Wagnerian inspiration inside a pre-existing building, the complex of Via Galliari $n$. 28 in Turin [7].

This small theatre offered a limited number of concerts, choreographic performances by Bella Hutter and Raja Markman and their school, sometimes joined by Gualino, and a few prose shows. The hosts addressed the invitations, made by Turin artists such as Casorati or Gigi Chessa, to an audience of guests chosen from among the members of the upper middle class of Turin and intellectuals. In some cases, the appointments set up at the theatre were valid for some artists as a test bench in parallel with the public and official exhibition on the stage of the Turin Theatre.

The building was constituted by a small rectangular theater, for just 100 spectators, with bas-reliefs and statues on either side of the proscenium realized by Casorati. The statues were supported by scarlet pedestals while the bas-reliefs were received in fourteen lunettes, consisting of sloping rectangles, two of them on the proscenium, two on the opposite wall and the remaining ones on the side walls.

Color is also a relevant theme for the creation of the theater. The hundred high chairs were made of polished black wood with gray pillows, the curtain was a gray cloth threaded with red and a black floor completed the chromatic harmony carefully studied by Sartoris [8]. In his written memoirs, 
Gualino attributed the design of the theatre only to Casorati.

The studies conducted by the historian Marco Pozzetto in the seventies instead demonstrate the fundamental role of Sartoris in the design of the small theater [9].

Today, related to this building, demolished in 1930, there are only a few photographs and the famous perspective views by Sartoris. From these drawings emerges the essentiality of the work, which in any case represents one of the first examples of modern architecture in Italy.

Sartoris' professional experience in Turin, corroborated by his constant contact with the major European artistic movements, led him to take part in some of the most famous international congresses. Following his participation as Italian delegate to the Congrès Internationaux d'Architecture Moderne (CIAM) in La Sarraz, Switzerland, in June 1928, Sartoris also participated to the first Congres International $d u$ Cinématographe Indépendant organized by the critic Robert Aron once again at the Castle of La Sarraz, from 2 to 8 September 1929. The participation of Sartoris at this Congress, once again as Italian delegate, is considered as the first concrete experience through which he has the opportunity to get closer to the themes of avant-garde theater. Together with Sartoris, the most important names of avant-garde art and architecture belonging to the Italian delegation take part to the congress, such as the futurist painter Enrico Prampolini, while Marinetti and Pirandello figured in the Honor Committee. The main purpose of the conference was to bring together the most prestigious personalities involved in international theaters and cinemas, not only in the architectural field, but also film directors and independent film critics, and discussing the state of art of the avant-garde cinema, promoting and encouraging the production of films that were independent, in fact, for commercial purposes, with the aim to create a permanent international organization: the aim was to highlight the artistic, moral and intellectual side of the independent film, considered until then as a simple industrial product. It was precisely during the congress that Sartoris has the opportunity to present to the public the project of his avant-garde cinema-theater for Geneva [10]:

A ce Congrès, trente Architectes appartenant aux différentes Nations avaient pris part. Le résultat e été une prise de contact féconde, entre les architectes, qui jusque là, travaillaient dans le même sens, sans avoir eu l'occasion de se rencontre et de cordonner leurs efforts. [...] Il est inutile d'insister ici sur l'importance que peut présenter, pour le Cinématographe International, la réalisation d'un tel Congres. Au moment où, dans le plupart des pays, les dirigeants du Cinéma Commercial imposent leur hégémonie, sans souci le plus souvent de la valeur artistique eu humaine de leurs productions, les Cinéastes indépendants ne peuvent avoir quelque chance de continuer leurs efforts qu'en se groupant et en coordonnant leur action [11].

In a letter dated 24 April 1929 Sartoris communicated to Hélène de Mandrot, owner of the Castle of la Sarraz and animator of the conference, who has prepared together with Fillì the first Italian avant-garde film and proposed it as a first screening during the congress. Sartoris also announced that he had asked Le Corbusier a foreword for a small brochure for the Ciné-clubs in Lausanne in which he presented for the first time his avant-garde theater project [12]. During the congress, some avant-garde films were projected, abstract and impressionist, like those of Viking Eggelinck and Hans Richter and some short movies that were censored at the time, such as Le Chien andalou produced and interpreted by Luis Buñuel and Salvador Dalí.

For Geneva, Sartoris proposed a theatre that would become a place of experimentation and research. In the architect's intentions, this theatre wanted to be something more than a traditional theatre hall: as was partly the case with the Gualino theatre, the one designed for Geneva was intended to be a place where ideas can meet and be compared, a stimulating testing ground for creative and recreational activities that can arise from Geneva's theatrical and intellectual environments. With this experimental theatre, Sartoris certainly laid the basis of the modern principle of stage space: the hall of the show, the heart of the building, has form and function sized and adjusted according to acoustic and visibility needs. The theater of the avant-gardes, experimental for the performances and shows proposed or for the materials used, not so much from the point of view of architecture or stagecraft, was clearly futuristic inspired and placed the accent on unusual and anomalous spaces, small in size and capacity, adaptable or transformable according to the requirements of the show. Of these same principles are examples the Teatro degli Indipendenti or Teatro Sperimentale, founded in Rome in 1922 by Anton Giulio Bragaglia and the Teatro Scribe of Turin inaugurated in 1925 following a recovery intervention funded by Gualino and coordinated by the critic art Lionello Venturi and the painter Chessa. It was also with this work that Sartoris experimented the concept of "integration of all arts" into architecture that was the highest expression of the arts, such as painting and sculpture, even if more generally he also considered cinema, theatre and music. In this concept, the use of colour also took on a fundamental component, as it was also linked to the theory of ambient lighting and musical compositions. According to Sartoris, the choice of the so-called "chromatic symphonies" [13] didn't represent a mere decorative component, but it was inserted as a whole within the design process (see Figure 2).

Conceived according to the dictates of rationalism, maximum structural linearity and almost no decorative sobriety, the theatre of Sartoris was in fact an architectural place particularly suited to the application of the concept of integration of all the arts. Although very similar to the first futurist projects of the early twenties of the twentieth century, the theater for Geneva is characterized by a so-called "structural linearity" that brings it closer to the upcoming Italian rationalist climate. 


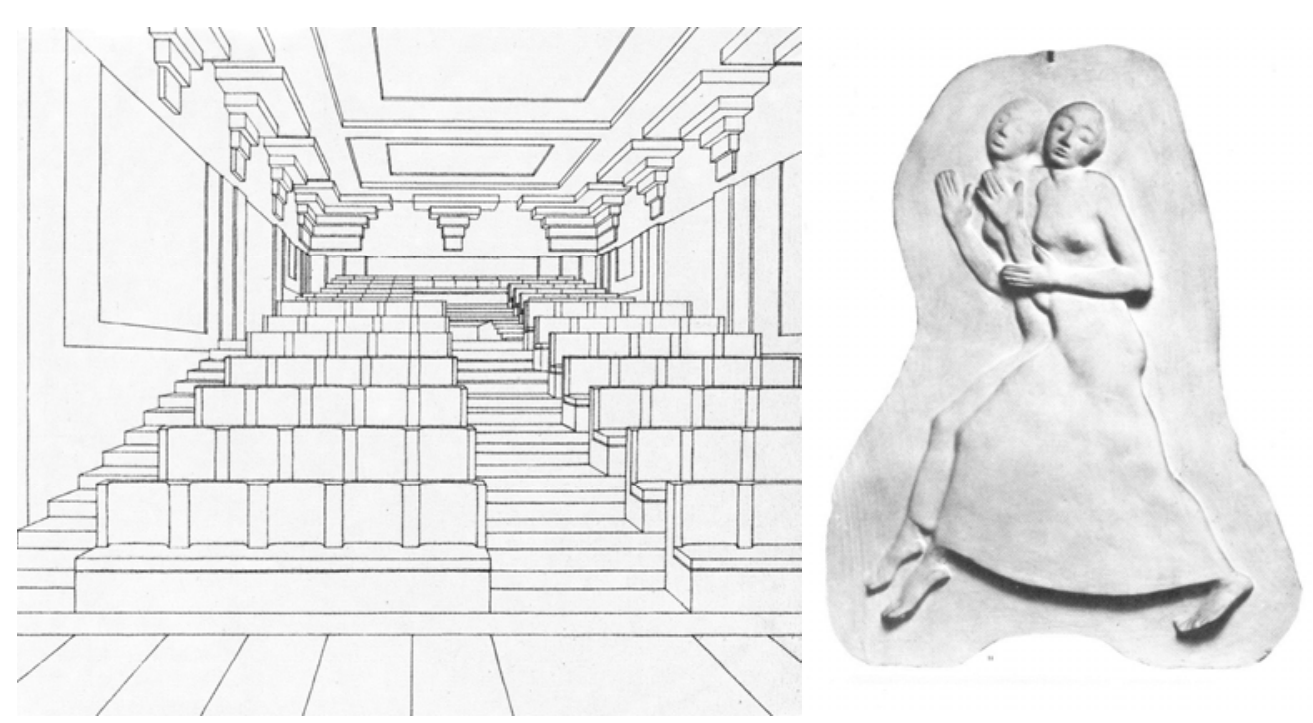

Figures 2. Private theatre for Gualino, perspective view of the hall from the stage and sculpture with dancers realized by Casorati (L. Pianzola, Alberto Sartoris, da Torino all'Europa. Milan: Alberto Greco Editore, 1990, 36).

This theatre project is not born for a specific context, like most of Sartoris' axonometries. This project does not seem to have a client or a territory to which it belongs. This tendency to create suspended objects outside their context is a form of representation typical of Sartoris, as well as its great limit. The axonometries of the project are in fact part of a fantastic and unrecognizable territory. This type of representation is probably the result of the conviction of the theoretical priority of design, understood as an essential tool of architectural representation. Sartoris in fact omitted to include trees, man and all those elements of the urban sphere that strongly characterize even the avant-garde painting. In this context, the representation used highlights the assembly of an artefact, as an object that can be decomposed and assembled through a simple system of aggregation of volumes. The analysis of the numerous axonometries made by Sartoris from the late twenties of the twentieth century highlights a constant geometric rigor in which the architect omits, to the point of completely eliminating the decorative element. The axonometric studies of the avant-garde theatre project represent the first evidence of the complete absence of decoration in which, reaching the extreme synthesis, the shape of the buildings becomes the only ornament. Sartoris' rigorous use of axonometry is not so much a reference to a corresponding built reality as an indicator of the rules of architectural space, due to its coherent abstractness. The axonometry used by Sartoris, starting from the urban compositions of 1922, reduced to essential features and well-defined volumes of immediate figurative perception can be considered as the purified and geometrical variant of the one already used during Futurism, that is, utopian and imaginative. For Sartoris, the theme of axonometric drawing therefore fulfils the function of a true Manifesto of Rational Architecture and is highlighted by the numerous publications of the author himself and by his continuous presence and participation in international conferences and exhibitions.

According to the critics of the time, with the design of the avant-garde theatre, "without picturesque elements" Sartoris was able to use the means of his art, adapting them to the taste and practical needs of his time. In both axonometries of the theatre, the project seems to reduce spaces to a minimum, while ensuring high quality made possible through a correct orientation of the volumes and through an adequate distribution of the rooms. Each room, however, seems to be multi-purpose and the result is an interesting compositional game despite the apparent simplicity of the volumes.

Observing the axonometry of this theatre, it's clear that Sartoris intended to present a project in which neither the type nor the construction system are precisely defined; only the title given by Sartoris to his design tables provides a general typological description of the project. The result of this design strategy is such as to cancel any reference or architectural content, due to the flexibility of any possible construction techniques adopted. After all, the refusal to qualify the space in which the theatre project is located will also characterize the subsequent axonometric representations by Sartoris [14].

The Sartoris' theater project highlights the great versatility of the spaces: the ground floor is a place for meetings, assemblies or temporary exhibitions and on the third floor there is the large rectangular hall equipped with the seats of the spectators arranged in movable steps. The element of innovation lies in the flexibility of the scene, where the stage allows the greatest number of changes in the shortest possible time. There are therefore no fixed roles: every room is multipurpose and everything is an intricate game of composition, despite an apparent simplicity. The maximum usability of the spaces combine with putting the public in the optimal conditions to enjoy the show, seemed to be the main interests of Sartoris in his project of avant-garde theater. He carefully studied the theater's project as a simple architectural complex, without examining, at least apparently, the issues related to the scenic building and the stagecraft. Sartoris therefore seemed to create a theater designed for the spectator. In addition to the dressing rooms and different service spaces, 
the subsidiary locations include several music and rehearsal rooms. So far away, for example, from the principles of Total Theater of Gropius, the Sartoris' scene project traces the setting of the Italian style with precise technical features. The avant-garde in his project is absorbed in the sculptural plastic of the complex and in the organization of spaces. In relation to the radical transformations of the stage space following the evolution of the avant-garde theatrical representations of the early twentieth century, it was possible to find further elements of innovation especially with regard the use of new construction materials such as iron, glass and concrete. Sound, light and movement are the elements that guided the Sartoris' project, especially as regards the design of the hall with 370 places sloping towards the stage. The study of the interior of the theatre can only be possible through the analysis of the drawings: the absence of side stages and the extreme simplicity of the arrangement of the furnishings used to avoid placing unnecessary acoustic barriers between the scene and the audience. Only eight steps separate the scene from the audience. From an architectural point of view, there seems to be no contamination between the spectator and the actor. Curiously, unusual ribbon openings (probably obscured during theatre performances) on the west wall of the building illuminate the hall. Some project sketches and geometric decompositions of the theatre floor plan reveal all the importance that Sartoris entrusts to geometry, understood as synthesis, as the rule for constructing the essential [15].

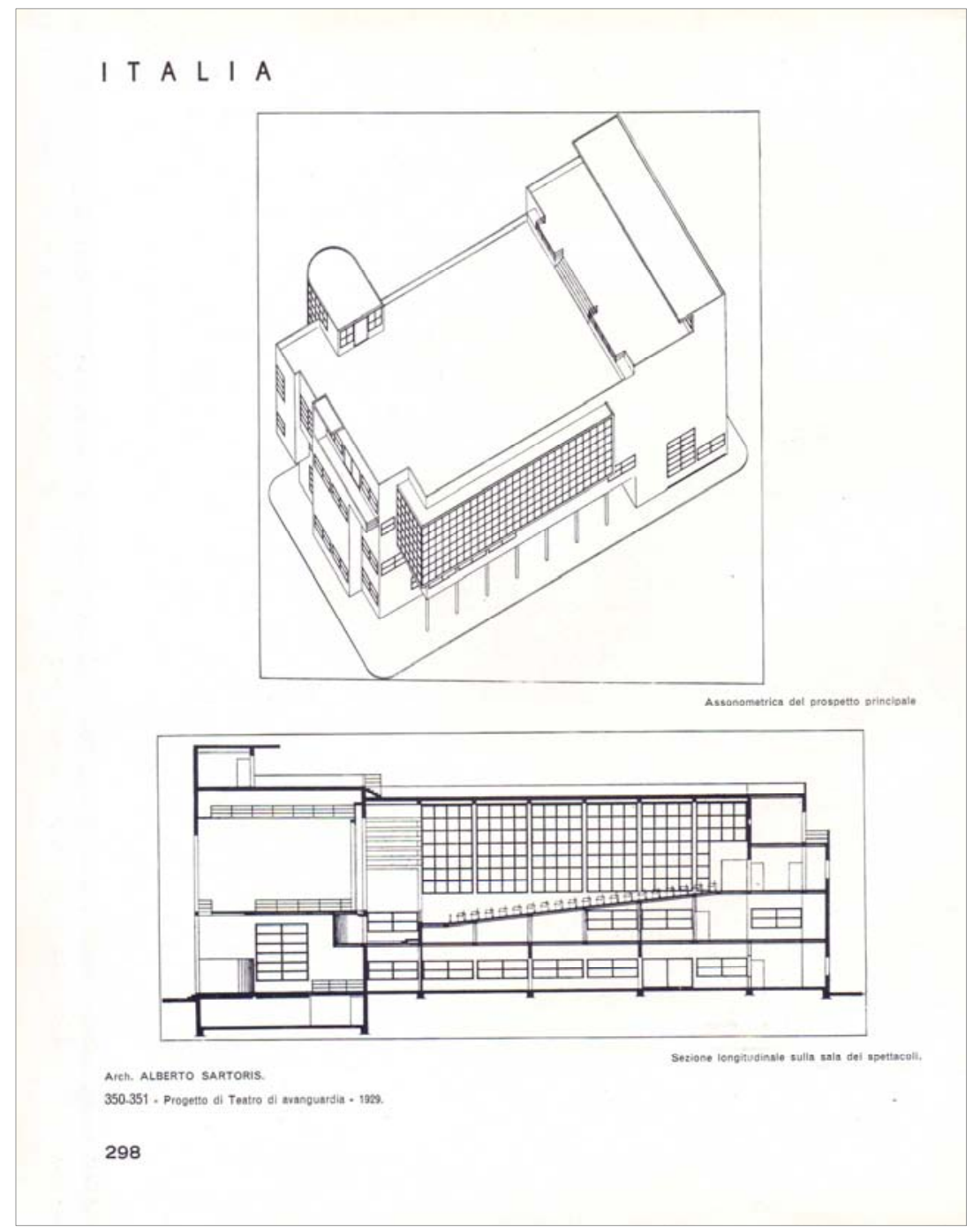

Figure 3. Project for the avant-garde theatre for Geneva, 1929-30 (A. Sartoris, Gli elementi dell'architettura funzionale. Milan: Ulrico Hoepli, 1932, 298).

For the spatial setting of his theatre, Sartoris seemed to have used the structures of the traditional theater, such as stage, warehouses, workshops: a large assembly hall, with many mobile bridges, elevators, cranes, motor elevators, department stores side, a large back stage, scenes transportable on rails. It was certainly up to the imagination of the directors and the skill of the performers to bring the theatre to life, just as it was up to the set designers to suggest, with simple means, the most suitable environment for the performance.

The impression is that, once the experiments of the avant-gardes are over, Sartoris returns to the datum of tradition, as if he were anchored, sure, to a substantial solidity that protects him from what he evidently considers to be the transience, the smokiness of the theatrical avant-garde in 
relation to the architectural avant-garde of the first decades of the twentieth century. It's a paradoxical phenomenon if we think of the great activity of Sartoris in the field of the artistic avant-garde. For unknown reasons, but perhaps not entirely unrelated to the cost and technical complexity of its realization, the project did not follow. Following the work of the Congres International du Cinématographe Indépendant, Sartoris was appointed Artistic Counselor of the Coopérative Internationale du Cinématographe Indépendant based in Paris, but dissolved after a short time. The attempt, however, made by Sartoris to conduct a real propaganda of independent cinema in Italy and Switzerland has not been followed. His theater for Geneva will never be realized, as for example his project was never published either in a brochure for the cine-clubs in Geneva or in the volume edited by Marinetti, Teatro Futurista, reissued in 1941.

The avant-garde theatre project remained therefore a real cultural project: Sartoris was able to gather the most important images of architectural experiments on theatre buildings within his volumes, the three editions of Gli elementi dell'architettura funzionale and the three tomes of the Encyclopédie de l'architecture nouvelle. For example, in the first edition of Gli elementi, Sartoris decided to publish numerous photographs of build works, he dedicated considerable importance to his projects by publishing thirty-six drawings of his unrealized works, including the theater project for Geneva. In fact, in relation to the purely self-promotional objective of his volume Sartoris included in all five images of the project of his theater between axonometries, sections and plans (see Figures 3-4).

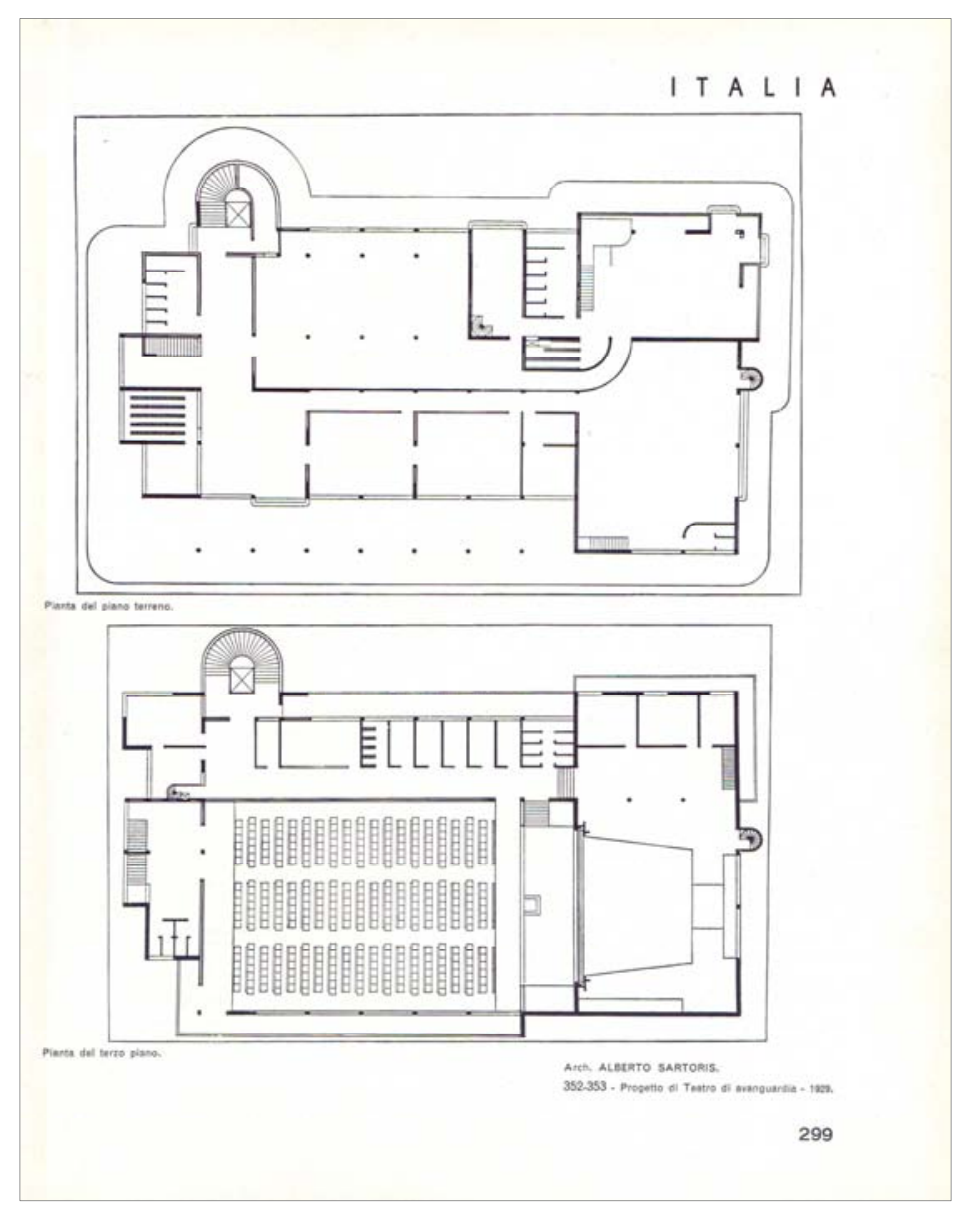

Figure 4. Project for the avant-garde theatre for Geneva, 1929-30 (A. Sartoris, Gli elementi dell'architettura funzionale. Milan: Ulrico Hoepli, 1932, 299).

The purpose of Gli elementi was twofold: on the one hand there was Sartoris' willingness to search for a strictly didactic and informative objective for his book and on the other hand his intentions were clear, clearly self-promotional, to see his name and his few projects matched with that of the most important icons of rational architecture of the time. In any case, the theater for Geneva has enjoyed great success and the images of the Sartoris project were published in the most important periodical magazines of the period, such as Futurismo of 1932 and inside La nuova architettura by Fillì of 1931. The two axonometries by Sartoris were also exhibited at the exhibition of Artisti Della nuova Italia, Künstler des neuen Italien, in Bern, held from 16 March to 4 May 1930 and published in the main monographs dedicated to Sartoris [16].

On the occasion of the celebrations of the second Rational Architecture Exhibition inaugurated on 27 March 1931 at the Galleria di Roma, the Italian-Swiss architect took part in the demonstrations with the exhibition of the two already known reproductions related to the avant-garde theater project and the project of the Geneva workers' houses. In addition, at the end of January 1932, just a few months after the publication of Gli elementi, Sartoris exhibition, the first large personal after the 
one in Turin in 1928, was set up at the Galleria del Milione in Milan and accompanied by an abundantly illustrated catalog edited by the Roman critic Pietro Maria Bardi with a circulation of 300 copies. The two axonometries of project of the avant-garde theater appeared in the catalog [17]. Following the publication of Gli elementi and thanks to the resounding success of the personal exhibition in Milan, in 1933 and 1934 numerous art galleries, both Italian and foreign, agreed with Sartoris the staging of several exhibitions dedicated to his first projects of rational architecture: the Galerie 23 in Paris, the Galleria Palladino of Cagliari, the Circolo degli Artisti of Turin, the Bragaglia fuori commercio of Rome and the Galleria degli Illusi of Naples hosted the most famous reproductions of the works of Sartoris, including the axonometric of his avant-garde theater, considered as the master of Italian rationalist architecture, the first that he has realized and the first that has powerfully framed Italian ideas and contributions to functional architecture.

\section{Results and Discussion: The Relevance of Theatre in Sartoris' Practice}

The analysis of the iconographic apparatus of Gli elementi makes possible also to retrace the diffusion of a specific perception of the architecture images of that period, especially in relation to theater architecture projects [18]. In fact, the careful selection of images, both of projects and built works, to be reproduced within the book, testifies the Sartoris' desire to bring together within a single volume the only images relating to the so-called "new architecture", highlighting the rigid rationalist criteria.

The three editions of Gli elementi (the first of 1932, the second of 1935 and the third of 1941) were destined to occupy, for about thirty years, a dominant position within the vast panorama of publications that critically deal with the architecture of the period. Although it was not configured as a real handbook belonging to the characteristic editorial collections of Ulrico Hoepli, Sartoris' volume was considered as a sort of "guide" for the innovators of the "new architecture" and a useful tool for the training of future generations of researchers and architects.

For this reasons, the critical reading of the architectural theater works published within the book can be a precious testimony of what were the projects or theater buildings reputed by Sartoris worthy to appear in his famous volume. The avant-garde movements in the field of the arts of the first half of the twentieth century have substantially involved also the architecture of the theater: therefore they induced designers and architects from around the world to apply progressive theories to new forms and architectural models intended for the show architecture. The Italian Futurism, the Dutch Neoplasticism and the Russian Constructivism introduced, with their manifestos, numerous debates and experiments, for example the use of new scenic elements and mechanical structures, to the advantage of a dynamic performances and shows. The radical revolution in the field of theater architecture between the nineteenth and twentieth centuries, redefined, in fact, the staging as a unitary creation, which harmoniously collaborated all the components of the show, including the architecture that contains it. Of this current, the integration of all the arts in architecture, Sartoris was certainly a tenacious exponent.

The dissemination of the results related to the early architectural experiments of the time was made possible thanks to the birth and the interest of numerous Italian and foreign architectural magazines: Das Neue Frankfurt in 1926, Domus and La casa bella in 1928 and L'Architecture d'Aujourd'hui in 1930, but also Architectural Record and The Architectural Forum in 1938, for example, were just some of the magazines that primarily testified to the gradual abandonment of the written text as the main means of communication of architectural thought and, secondly, the affirmation of a new transmission of ideas through the image. The American journal Architectural Record, for example, in May 1930 has dedicated an entire issue to the architecture of the theater publishing numerous pictures of realized buildings and projects, such as those related to the interior of the teatro intimo of Karl Schneider in Hamburg, in 1930. In addition, numerous theatre magazines of the time have, such as Scenario, Ars Nova or Sipario in Italy, Theater Heute in Germany and Theatre Arts in United States, emphasized aspects related to architecture, acoustics and lighting systems.

And more, some important books published since the twenties, albeit in different ways, through the spectacular nature of the photographs published explore the articulation of the theatrical structure, the distribution of the services, the materials to be used, the machinery for the scenography and all the reflections that have as the ultimate goal the search for the best solutions for seeing and hearing are not compromised. For example, the volume of Irving Pichel, Modern Theater, of 1925 is defined, thanks to the abundant published tables out of print, as a first panoramic overview of contemporary world architecture that pays particular attention to the definition of national architectural features in an exact and exhaustive manner. Also distinguished for the attention paid to the illustrative apparatus also the volume Modern Theaters and Cinemas by Philip Morton Shand published in 1930. In Italy, particularly interesting is Italia nuova, architettura nuova by Virgilio Marchi published in 1931, within which the author, considered a "renewal of Italian scenography and scenography", examined in twenty short chapters, "the most current questions of contemporary architecture", from rationalism to the most famous achievements of sports, religious, funeral and theater construction. The volume of Bruno Moretti, Teatri published by Hoepli in 1936 represents only one of the most important publications that best testify the editorial and the attention to a predominantly photographic structure of the book, with 39 illustrated examples and 140 photographs, opened the discussion with a wide excursus of the historical information of the theater's architecture and dedicated ample space to detailed technical apparatus relating to acoustics, the stagecraft, the lighting for the project of the building and the hall for spectators. These editorial references 
have certainly influenced Sartoris during the preparation of the first edition of Gli elementi and, as such, have also determined some of his most intransigent compositional and editorial choices, in relation for example to the layout of the 676 illustrative tables inside the book. Within the first edition of Sartoris' book he stated that since the beginnings of European rationalism, architectural solutions based on a new interpretation of glass soon encountered a special inclination with the early modernists and defined the architecture of the theater as a complete example of the various constructive possibilities of contemporary rationalism.

The first new experiments in the architectural field aimed at a greater flexibility of the building, until sometimes to the abolition of the physical division between spectator and actor, represented by the proscenium. The idea of transformation of the scene and the theatrical representation allow us to reach metaphysics of architecture. These are the same years as the "experimental cinema" and the result was a total transformation of the aspects concerning the building itself and of the theater function.

Sartoris saw in the architecture of the theater the constructive typology in which the aspects of an ardently polemical character were more evident, which were testimony to the functional architecture, propitiatory of the imagination and the plastic fruitfulness of the new spirit: "The stairs will be replaced by moving platforms, as in theaters with continuous shows you will certainly get to clear the rooms, after each performance, without the use of the usual stairs, but with movements of floors, tunnels and construction assemblies. Architecture will become increasingly dynamic, not just increasingly mechanical" [19]. Also in other parts of his book, he insisted on the mechanical aspect of the theater building, underlining, on the one hand, the importance to providing it with structures that allow perfect use by the public, and on the other to build it in such a way that acoustics and visibility are optimal.

These principles can be found for example in Walter Gropius' total theater project, and to which Sartoris has dedicated ample space within the section devoted to Germany of his book, publishing three images and accompanying them with a long caption. Also in the German section Sartoris published the project of the festival of Osnabruck celebrations by Friedel Vordemberge-Gildewart and a perspective view of the teatro attivo for the city of Kharkow by Marcel Breuer with Gustav Hassenpflug and Mamontoff of 1930. Sartoris also dedicates ample space to the project of the teatro intimo with 700 seats in Hamburg by Schneider. These projects published in Gli elementi, however daring and brand new (but not yet tested by experience) were already overcome by the new problem imposed on architects and technicians: that of mass theater, was a concept intended for large gatherings of people and shows particularly suited for size and character to this new type of theater [20].

\section{Conclusion}

The result of this study highlights how much is still possible to investigate within the professional and academic career of Sartoris. It was evident how the images appeared within the three editions of Gli elementi were a precious testimony of how much this volume has marked and influenced the perception of the architectural image from the early thirties of the twentieth century. In confirmation of the popularity achieved by Sartoris, at the beginning of the fifties, numerous critics and architects struck by the illustrations reproduced in his volumes began to ask him for the shipment of photographs and drawings, as they wanted to represent them in various articles and architectural publications.

Sartoris' books represented also the most considerable effort to unify the images related to rational architecture and his rich editorial production has certainly constituted the essential basis for the construction of the fame that the Italian-Swiss architect has nourished over the years up to already considered in 1932 by Bardi one of the "crusaders of the new architecture".

The axonometric representations of the theatre project for Geneva, as well as the project of the small theatre for Gualino, are just some of the first attempts made by Sartoris to give light to a new form of architectural experimentation, where the principles of the so-called "new architecture" of the early twentieth century are highlighted through a careful study of the spaces and proportions related to the architectural composition. Sartoris' numerous projects were emblematic of how he was able to interpret Modernism, throughout his long career, both in the years before the Second World War and in the years of post-war reconstruction up to his most recent contemporary works, in which clear and pure volumes, the use of colors and innovative materials indicated how architectural Rationalism could still evolve [21]. These experiments concerned above all the different design solutions in order to obtain the best visibility and acoustics, fundamental characteristics for the best enjoyment of the theater, as well as to optimize its capacity. The emergence of rational architecture and, at the same time, the strong background of nineteenth-century architecture from which Sartoris has certainly learned during the study phase has also allowed experiments from a compositional point of view [22]. Although the avant-garde theatre project has not been realized, in Sartoris' long career it has assumed the role of a true "icon of modernity".

\section{References}

[1] A. Baudin (ed.), Photographie et architecture moderne. La collection Alberto Sartoris. Lausanne: Presses polytechniques et universitaires romandes PPUR, 2003; A. Baudin (ed.), Photography, Modern Architecture and Design. The Alberto Sartoris Collection, Objects from the Vitra Design Museum. Lausanne: Presses polytechniques et universitaires romandes PPUR, 2005; A. Baudin, Le monde d'Alberto Sartoris dans le miroir se ses archives. Lausanne: Presses polytechniques et universitaires romandes PPUR, 2017.

[2] J. Gubler and A. Abriani, Alberto Sartoris: dall'autobiografia alla critica. Milan: Electa, 1990. 
[3] M. Pozzetto, "Alberto Sartoris. Laurea h. c. a Losanna," Studi Piemontesi 1 (March 1976): 108.

[4] A. Sartoris, Gli elementi dell'architettura funzionale. Sintesi panoramica dell'architettura moderna. Milan: Ulrico Hoepli, 1932. Afterwards, the title of Sartoris' book will be shortened to Gli elementi.

[5] C. Leprette, L'itinéraire magique d'Alberto Sartoris. Florence: Alinea, 2005.

[6] Fillìa, "Architettura futurista," Futurismo, November 6, 1932.

[7] See, Folder 0172.04.0027, Théâtre Gualino, à Turin, Culture et vie sociale, Archives de la construction moderne, École Polytechnique Fédérale de Lausanne (thereafter Acm-EPFL).

[8] L. Pianzola, Alberto Sartoris, da Torino all'Europa. Milan: Alberto Greco Editore, 1990.

[9] M. Pozzetto, "Alberto Sartoris e il teatrino privato di casa Gualino," Studi Piemontesi 3, November 1974: 331-4.

[10] See, Folder 0172.04.0043, 1929-1930, Projet de théâtre pour Genève, Acm-EPFL.

[11] "At this Congress, thirty architects from different nations took part. The result was a fruitful contact between architects, who until then had been working in the same direction, without having had the opportunity to meet and coordinate their efforts. It's useless to insist here on the importance that the realization of such a Congress may have for the International Cinematographer. At a time when, in most countries, Commercial Cinema executives are imposing their hegemony, most often without concern for the artistic and human value of their productions, independent filmmakers can only have any chance of continuing their efforts by joining forces and coordinating their action". Typewritten letter, without sender and without date, to Sartoris, folder AS.03.027.03, Acm-EPFL.

[12] Letter from Sartoris to Hélène de Mandrot, 24 April 1929, folder 0172.01.0039 GA05, Acm-EPFL.
[13] A. Sartoris, Tempo dell'Architettura. Tempo dell'arte. Cronache degli Anni Venti e Trenta. Rome: Fondazione Adriano Olivetti, 1990, 95.

[14] C. Gavello, "Alberto Sartoris e la pratica del disegno come forma di espressione," Il Disegno di Architettura 43, July 2018, $39-43$

[15] A. Cuomo, Alberto Sartoris. L'architettura italiana fra tragedia e forma. Rome: Edizioni Kappa, 1978, 36.

[16] R. Giolli, Alberto Sartoris, Collezione Architetti Nuovi, n. 3, Milan: Edizioni di Campo Grafico, 1936; A. Sartoris, Carignano nuova, la città nella città. Milan: Edizioni Sapiens, 1994.

[17] P. M. Bardi, Alberto Sartoris. Esposizioni delle assonometrie dell'architetto Alberto Sartoris, exhibition catalog. Rome: Galleria del Milione, 1932.

[18] C. Gavello, “Alberto Sartoris: Gli elementi dell'architettura funzionale. Il libro come strumento per la costruzione della fama (1926-1992)" (Ph.D. diss., Politecnico di Torino, July 2016).

[19] A. Sartoris, Gli elementi, op. cit., 52.

[20] A. Martini, "Teatri e teatri d'opera in Italia fra le due guerre mondiali. Modelli, protagonisti, progetti," in Architettura dell'Eclettismo. Il teatro dell'Ottocento e del primo Novecento. Architettura, tecniche teatrali e pubblico, L. Mozzoni and S. Santini (eds.), Naples: Liguori editore, 2010, 321-79.

[21] D. Pastore, “Alberto Sartoris e il '900/1998," Simultaneità 4 (1999), 32.

[22] C. Gavello, "Le vie dell'architettura e della città. Alberto Sartoris e l'attualità del Razionalismo," in Spazio, Tempo Utopia. Scritti e progetti per Sewing a small town 2015-2016, A. Bologna (ed.), Milan: FrancoAngeli, 2017, 119-36. 